\title{
LIBERATION AND EXILE: THE FATE OF CIVILIANS DURING THE RUSSO-TURKISH WAR OF 1877-1878 IN BULGARIAN AND TURKISH HISTORIOGRAPHY ${ }^{1}$
}

\section{Krzysztof Popek}

(D) http://orcid.org/0000-0001-5864-5264

Jagiellonian University, Cracow

\begin{abstract}
The Russo-Turkish War of 1877-1878 is traditionally called as the "Liberation War" by the Bulgarians. The conflict led to gaining freedom from the "Turkish Yoke" and started creation process of the modern Bulgarian state. The Turkish perspective on these events is significantly different. The War of 1877-1878 is remembered through the lens of the tragic experience of refugees (muhajirs) and the suffering of the Muslim civilians linked to the pogroms, emigration and exile. The paper will focus on the depiction of the fate of civilians during the conflict in contemporary Bulgarian and Turkish historiography, in which the topic is marked not only by the reliability of historical research, but also by the presence of stereotypes (as is the whole history of the $19^{\text {th }}$-century ChristianMuslim relations in Bulgaria).
\end{abstract}

Keywords: Russo-Turkish War of 1877-1878, war victims, historiography, Bulgaria, Turkey, the Balkans.

\section{INTRODUCTION}

The Russo-Turkish War of $1877-1878$ is traditionally called the "Liberation War" by Bulgarians. The conflict led to freedom from the "Turkish yoke" and started the process of creation of the modern Bulgarian state. This way of presentation of these events can be illustrated by works by such historians as Konstatin Kosev, Stefan Doynov, Tsonko Genov, or Georgi Georgiev, as well as by Russian authors (for example, Boris Nikolayevich Bilunov). The Turkish perspective (represented

${ }^{1}$ Research presented in this article was financed by the grant of the Polish National Science Center: The Balkan Migration Processes in the 19th Century. Cases of Bulgaria and Serbia (2017/25/N/ HS3/00576).

Address for correspondence: popek.kj@gmail.com 
by Ömer Turan, Bilâl Şimşir, ${ }^{2}$ and Kemal Karpat, but also by the Western authors as Justin McCarthy and William Holt) on these events is markedly different. The War of 1877-1878 was remembered through the lens of the tragic experience of refugees $\left(\right.$ muhajirs $^{3}$ ) and the suffering of the Muslim civilians linked to the pogroms, emigration, and exile. ${ }^{4}$ The Bulgarian and Turkish narratives about these events are codified not only by reliable historical researches (however, they are often quite selective: Bulgarian perspective is reconstructed based on the local and Russian sources, Turkish - with the Ottoman and Western materials) but also by stereotypes, as is the whole $19^{\text {th }}$-century history of Christian-Muslim relations in Bulgaria. Historiographical visions of the Russo-Turkish War of 1877-1878 usually focused on the political and military aspects of the conflict, which is most visible in Bulgarian and Russian historiography. ${ }^{5}$ The problem of the fate of civilians during these events is less precisely described - that is why the paper focuses on this issue.

Why is the War so important? The conflict of $1877-1878$ had a crucial impact on the population composition of the Bulgarian lands. The ethnic and religious map of Bulgaria, based on the balance of Christians and Muslims, was changed to the ratio of 3:1 in favour of the Bulgarians. ${ }^{6}$ The exodus of Muslims was the largest in the territories where the warfare was the most intense, e.g. in Western and Central Bulgaria. In the North-Eastern parts, which Russians did not occupy during the War, the largest

2 The most important contribution of the author to the knowledge about the topic is the collection of documents: Rumeli'den Türk Göçleri. Belgeler, cilt I: Doksanüç Muhacereti. 1877-1878, ed. B.N. Şimşir, Ankara 1968. However, the most important conclusions about the War of 1877-1878 were also presented by Bilâl Şimşir and other Turkish historians in the books and articles published in English.

${ }^{3}$ Muhajir - a Muslim refugee or migrant; the word comes from the Turkish "muhaçir," which means the follower of Mohammed, who joined the Prophet in Mecca and went with him to Medina.

${ }^{4}$ The best example of this perspective is the book: W. Holt, The Balkan Reconquista and Turkey's Forgotten Refugee Crisis, Salt Lake City 2019.

${ }^{5}$ See: К. Косев, С. Дойнов, От Шипка и Плевен до Сан Стефано и Берлин, София 2007; С. Дойнов, Българската общественост и Руско-турската освободителна война (1877-1878), София, 1978; Ц. Генов, Освободителната война 1877-1878, София 1978; Г. Георгиев, Освободителната война 1877-1878: енциклопедичен справочник, София 1986; Leksykon tradycji butgarskiej, ed. G. Szw at-Gyły b ow a, Warszawa 2011, pp. 340-345; Россия и Болгария: K 125-летию русско-туреикой войны 1875-1878 г2., Москва 2006; Б.Н. Билунов, Болгария и Россия, Москва 1996, pp. 148-160; В.Н. В иноградо в, “Последняя русско-турецкая война 1877-1878 годов” [in:] История Балкан: Судьбоносное двадцатилетие (1856-1878 г2.), ред. В.Н. В ин оградов, Москва 2012, pp. 299-327; idem, “Боевое содружество народов России и Балкан во время русско-турецкой войны 1877-1878 гг.” [in:] Центральная и Юго-Восточная Европа в Новое время, Москва 1974, pp. 205-213; The Polish literature about the War of 1877-1878 is comparatively small and usually reproduces the Bulgarian and Russian visions about these events. See A. Giza, Stowianofile rosyjscy wobec kryzysu bałkańskiego w latach: 1875-1878, Wrocław 1982; B. B rodeck i, Szypka i Plewna 1877, Warszawa 1986.

${ }^{6}$ FO 195/1077/332, Reade to Elliot, Constantinople 5.12.1876; B. Şimşir, The Turks of Bulgaria (1878-1985), London 1988, p. 5; A. Eminov, "Islam and Muslims in Bulgaria: A Brief History," Islamic Studies 1998, vol. 36, no. 2-3, p. 213; A.M. Mirkova, "Population Politics' at the End of Empire: Migration and Sovereignty in Ottoman Eastern Rumelia, 1877-1886," Comparative Studies in Society and History 2013, vol. 55(4), p. 966; O. Köse, "The Policies of the Bulgarian State towards the Minorities (1878-1914)," Sosyal Bilimler Araştırmaları Dergisi 2012, vol. 3(6), p. 217. 
Islamic community has remained until today. For example, the Tsarist Army did not enter Shumen and Varna. The Rhodope Mountains, which became the asylum for escaping muhajirs, were a similar case. ${ }^{7}$ The importance of the war for Bulgarians is obvious in many different aspects. According to the Bulgarian historian Dimit" $r$ Sazdov, the War resulted not only in the creation of the Bulgarian modern state, but was also a "bourgeois-democratic and agrarian revolution" linked to the liquidation of feudalism in that area. ${ }^{8}$ The Bulgarian geographer Anastas Ishirkov said that the Liberation War had been linked with the end of the Bulgarian attachment to family lands and fathers' graves - it had started their dynamic migrations on an unprecedented scale. ${ }^{9}$ The events of $1877-1878$ were significant not only for the Bulgarian lands, but for the Ottoman Empire as well. It started crucial socio-political changes for the "sick man of Europe." Movements of people on an unprecedented scale and the transfer of goods led to the collapse of the traditional Ottoman system of power and social order. In a longer perspective, the circumstances created the basis for the development of new ideas among the society "uprooted" by the mass migrations and the experience of refuge. Pan-Islamism, nationalism, secularism, populism, and socialism contributed to the collapse of the monarchy and the birth of the national Turkish state at the beginning of the $20^{\text {th }}$ century. Of course, before and after 1878 , there were a series of crucial events for the Ottoman Muslims, but, due to Kemal Karpat, the Russo-Turkish War of 1877-1878 was an important stage of that process. ${ }^{10}$ The percent of Muslims in the Ottoman Empire increased by $75-80 \%$ after the conflict, which was linked to the territorial changes such as the loss of the lands dominated by Christians and Muslims' migrations. Later, the muhajirs created the foundations of the Turkish society and state. ${ }^{11}$

${ }^{7}$ A. Eminov, Turkish and Other Muslim Minorities in Bulgaria, London 1997, p. 78; idem, "Islam and Muslims," p. 213; След Сан Стефано и Берлин 1878 г. Изследване, документи и материали за освобождението на Североизточна България от османска власт, съст. В. Тонев, София 1999, pp. 33, 42-43; Дж. Маккарти, Смърт и изгнание: Етническото прочистване на османските мюсюлмани (1821-1922), прев. К. Панайотова, София 2010, p. 84; Ö. Turan, The Turkish Minority in Bulgaria (1878-1908), Ankara 1998, p. 106; M. Methodieva, Pan-Islam, the Porte and Education: Ottoman Support for Muslim Schools in the Bulgarian Principality, 1878-1908, Ankara 2001, p. 22; Страници от българската история. Очерк за ислямизираните българи и националновъзродителния процес, ред. Х. Христов, София 1989, р. 50; Н. Илиева, Турската етническа група в България (1878-2001), София 2010, pp. 34-35.

8 Д. Саздов, М. Лалков, Т. Митев, Р. Мишев, В. Мигев, История на Третата българска държава, София 1992, р. 23.

9 А. Иши иков, “Град Варна,” Периодическо списание 1905, кн. 65, р. 223.

${ }^{10}$ K. Karpat, Studies on Ottoman Social and Political History, Leiden-Boston-Koln 2002, pp. 354-355.

11 Ibidem, pp. 377-378. 


\section{WAR VICTIMS AND REFUGEES}

The number of civilian victims during the War of 1877-1878 was enormous in the context of the earlier conflicts in the Balkan Peninsula. First of all, the Muslim community suffered death and exile to the greatest extent. Due to the chaos during these events, later returns, and a lack of reliable statistical sources, the estimation of the number of Muslim victims and refuges is not an easy task. There is a big difference between the calculations proposed by various researchers. Berna Pekesen, Bilâl Şimşir, Osman Köse, Salahi Ramadan Sonyel, and Mirosław Dymarski hold the view that 200,000-500,000 Muslims died and 1,000,000 were forced to migrate during the conflict. ${ }^{12}$ Justin McCarthy and Nurcan Özgür-Baklacioglu estimate that about 500,000 Muslims took refuge in 1877-1878 and about half of them died as a result of war operations, hunger, diseases, and cold. ${ }^{13}$ Kemal Karpat writes about $750,000-1,000,000$ muhajirs and 200,000-300,000 victims of the pogroms. $.^{14} \mathrm{Hü}-$ seyin Memişoglu expresses the conviction that 350,000 Muslims died and 600,000 were forced to escape. ${ }^{15}$ According to Ömer Turan, 800,000 Muslim civilians from the Bulgarian lands were murdered or permanently left their homes. ${ }^{16}$ Bulgarian historians and researchers, who are closer to the Bulgarian perspective, use other numbers. Roumen Daskalov wrote about 100,000 Turks, who were forced to emigrate or were killed during the War. ${ }^{17}$ Konstantin Jireček estimated probably the lowest number - according to the Czech historian, between 1877 and 1890, a total of 100,000 Muslims left the Bulgarian lands. ${ }^{18}$ In 1916, Kiril Popov held the view that 135,000 muhajirs left Bulgaria during the Liberation War. ${ }^{19}$ Richard Crampton, Alexandre Toumarkine, and Bernard Lory are inclined to believe that 130,000-150,000 Mus-

${ }_{12}$ S.R. Sonyel, Minorities and the Destruction of the Ottoman Empire, Ankara 1993, p. 233; B. Şimşir, The Turks of Bulgaria, pp. XII, 5, 17; M. Dymarski, Konflikty na Batkanach w okresie ksztaltowania się państw narodowych w XIX i na początku XX wieku, Wrocław 2010, p. 129; O. Köse, "The Policies of the Bulgarian State," p. 218; B. Pekes en, "Expulsion and Emigration of the Muslims from the Balkans," European History Online 7.03.2012, http://www.ieg-ego.eu/pekesenb-2011-en [accessed: October 18, 2015].

13 Дж. Маккарти, Смърт и изгнание, pp. 126-129; N. Özgür-Baklacioglu, "Dual Citizenship, Extraterritorial Elections and National Policies: Turkish Dual Citizens in the Bulgarian-Turkish Political Sphere," Slavic Eurasian Studies 2006, no. 9: Beyond Sovereignty: From Status Law to Transnational Citizenship?, p. 321.

${ }^{14}$ K. Karpat, Ottoman Population 1830-1914. Demographic and Social Characteristic, London 1985, p. 75; idem, "Introduction: Bulgarian Way of Nation Building and the Turkish Minority" [in:] The Turks of Bulgaria: The History, Culture and Political Fate of a Minority, ed. K. Karpat, Istanbul 1990, p. 12; idem, Studies on Ottoman, pp. 369-370.

${ }_{15} \mathrm{H}$. Memişoglu, The Education of the Turks in Bulgaria, Ankara 1992, pp. 7-8.

16 Ö. Turan, The Turkish Minority, p. 145.

${ }^{17}$ Р. Даскалов, Българското общество 1878-1939, т. 2: Население, общество, култура, София 2005, р. 36.

${ }_{18}$ К. Иречек, Княжество България. Негова повърхнина, природа, население, духовна култура, управление и новейша история, ч. І: Българска държава, Пловдив 1899, p. 61.

19 Per: Н. Или в ва, Турската етническа група в България, р. 26. 
lims from the Bulgarian lands took refuge at that time, and 75,000-80,000 came back to their homes after the War. ${ }^{20}$

What is also worth mentioning is the estimated data about the Muslim refugees and victims in the entire Balkans. Wolfgang Höpken, Raymond Detrez, and Mila Maeva assumed that 1,500,000 Muslims took refuge in 1877-1878 on the scale of the whole region. ${ }^{21}$ According to Marija Pandevska, that number was between 600,000 and $1,000,000 .{ }^{22}$ Youssef Courbage pointed out that the total number of the Muslims refugees of the wars of $1877-1878$ and 1912-1913 was 1,500,000. ${ }^{23}$ According to the Ottoman authorities, on $27^{\text {th }}$ of November 1878 , exactly 729,127 emigrants were waiting for a transfer to Anatolia in different parts of the Balkans or had already left, which could also illustrate the scale of the Muslim exile during the War. ${ }^{24}$

Generally, the number of Muslim war refugees and victims in Bulgarian lands is estimated between 100,000 and 1,500,000. The most reliable method of calculating the scale of this phenomenon is to compare of the official data about the population of Bulgarian lands before and after the Russo-Turkish War of 1877-1878. However, there is a problem with that - the Danube Vilayet and the Plovdiv and Sliven Sandjaks overlapped with the later Principality of Bulgaria and Eastern Rumelia only to a certain extent. In the case of the North-Bulgarian lands (e.g. the Danube Vilayet and later Principality of Bulgaria), there was a need to separate the population from Dobruja and the region of Nish, and to attach a band of land in the south, up to the Balkan mountains. ${ }^{25} \mathrm{~A}$ more important problem is linked to the inaccuracy

${ }^{20}$ R. Crampton, Bulgaria, Oxford 2007, p. 426; Б. Лор и, Съдбата на османското наследство. Българската градска култура 1878-1900, прев. Л. Янакиева, София 2002, p. 46; A. Tou markine, Les migrations des populations musulmanes balkaniques en Anatolie (1876-1913), Istanbul 1995, p. 33.

${ }^{21}$ R. Detrez, Historical Dictionary of Bulgaria, Lanham-Toronto-Oxford 2006, p. 167; М.М. Маева, Българските туричи-преселеници в Република Туричия (Култура и идентичност), София 2006, p. 19; W. Нӧрken, "Der Exodus: Muslimische Emigration aus Bulgarien im 19. und 20. Jahrundert" [in:] Osmanen und Islam in Südosteuropa, eds. R. La u er, H.G. Maj er, Berlin-Boston 2014, p. 314; A. Kalionski, Communities, Identities and Migrations in Southeast Europe, Sofia 2014, p. 37.

22 М. Пандевска, Присилни миграции во Македонија во годините на Големата источна криза (1875-1881), Скопје 1993, p. 91; M. Pandevska, "Migration of the Muhajirs in Macedonia during the Great Eastern Crisis (1875-1881),' Balcanica Posnaniensia. Acta et studia 2001, vol. 21/22, p. 106 .

${ }^{23}$ Y. Courbage, "Demographic Transition among Muslims in Eastern Europe," Population: An English Selection 1992, vol. 4, p. 163.

24 B. Şen, "Empires from the Margin: Bosnian Muslim Migrants between Ottoman Empire and the Austro-Hungarian Empire - Petitions of the Returnees," Balkanistic Forum 2015, no. 3: Emigrants and Minorities: The Silenced Memory of the Russo-Ottoman War 1877-1878, p. 15.

25 The Human Rights of Muslims in Bulgaria in Law and Politics since 1878, Sofia 2003, p. 13; A. Eminov, "The Status of Islam and Muslims in Bulgaria," Journal Institute of Muslim Minority Affairs 1987, vol. 8(2), p. 284. For example, due to the calculations of Justin McCarthy, in 1877, 1,502,000 people lived in the later Principality of Bulgaria and Eastern Rumelia. During the War, 17\% Muslims $(262,000)$ died, and another 34\% (515,000) emigrated and never came back home. [J. McCarthy, "Muslims in Ottoman Europe: Population from 1880 to 1912," Nationalities Papers 2000, vol. 28, no. 1, p. 34]. Ömer Turan estimated that in the 1870s, 1,600,000 Muslims lived in the Bulgarian lands. According to the Turkish historian, that number decreased by half during the War, which means that 800,000 Muslims died or took refuge in 1877-1878. [Ö. Turan, K.T. Evered, "Jadidism in South-Eastern Europe: The 
of the statistics. For example, according to British reports, in 1869, 3,500,000 people lived in the Danube Vilayet: 1,725,000 Bulgarians, 1,200,000 Turks ("Asiatic and Slavic"), 240,000 Tatars, 100,000 Albanians, 100,000 Circassians and Abkhazians, 45,000 Serbs, 30,000 Romanians, 20,000 Roma, 18,000 Greeks, 10,000 Russians, 8,000 Jews, and 4,000 Armenians ${ }^{26}$ However, after a confrontation with other sources, these data seem to be significantly overestimated. According to the Ottoman census, in 1864, in the Danube Vilayet (as it was said, more or less the territory of the Principality of Bulgaria) 1,994,827 people lived, among whom 1,175,601 were non-Muslims (mainly Bulgarians) and 819,226 Muslims. ${ }^{27}$ In 1881, 2,007,919 people lived in the Principality: 1,145,507 Bulgarians, 527,284 Muslims, 11,444 Greeks, and 123,684 others. ${ }^{28}$ Before the War, in the Plovdiv and Sliven Sandjaks (e.g. later Eastern Rumelia), 210,000 Muslims lived, after 1878 - 120,000..$^{29}$ According to these data, the decrease of the Muslim population in the Bulgarian lands amounted to about 380,000 , i.e. $35 \%$. Of course, this kind of the calculations are approximate, and it is impossible to count the precise number of Muslim refugees and victims during the conflict.

The fate of Muslims during the Bulgarian Liberation War was concealed by historiography for a long time. Mark Mazower raises this problem, quoting the words of the British traveller Edith Durham:

When a Moslem kills a Moslem, it does not count. When a Christian kills a Moslem, it is a righteous act; when a Christian kills a Christian it is an error of judgment better not talked about; it is only when a Moslem kills a Christian that we arrive at a full-blown atrocity. ${ }^{30}$

In Western and Balkan historiography the question of pogroms and Muslim exile during the War was undoubtedly overshadowed by the narrative about the brutal suppression of the April Uprising and the massacres of Bulgarians in 1876-1878. ${ }^{31}$

Influence of Ismail Bey Gaspirali among Bulgarian Turks," Middle Eastern Studies 2005, vol. 41, no. 4, p. 483]. According to Valeri Stoyanov, there were 1,000,000-1,500,000 muhajirs and war victims. He based his estimate on the data that 2,582,385 Bulgarians and 3,913,354 non-Bulgarians (among others $2,000,000$ "Turks") lived in the Bulgarian lands in 1868; after the Liberation that number decreased to 466,000 Turks, 6,000 Tatars, 20,000 Pomaks, and 98,000 Muslim Roma. [В. Стоянов, Турското население в България между полюсите на етническата политика, София 1997, pp. 60-61].

${ }^{26}$ Vide: FO, 881/2956/3-4, General Report by Sir R. Dalyell on the Vilayet of the Danube, London 1.03.1869; S.D. Gruber, Selected Muslim Historic Monuments and Sites in Bulgaria, Washington 2010, p. 4.

${ }^{27}$ М. Тафрова, Танзиматът, вилаетската реформа и българите. Администрацията на Дунавския вилает (1864-1876), София 2010, p. 84.

${ }^{28}$ K. Karpat, "Introduction," p. 12.

${ }^{29}$ FO, 881/3574/3, 5, Statistical Information as to the Populations of European Turkey, printed for the use of the Foreign Office, June 1878; K. Karpat, Studies on Ottoman, p. 370; Н. Тодоров, Балканският град XV-XIX век. Социално-икономическо и демографско развитие, София 1972, p. 307.

${ }^{30}$ Per: M. Mazower, The Balkans: From the End of Byzantium to the Present Day, Phoenix 2002, p. 12.

${ }^{31}$ K. Karpat, Studies on Ottoman, p. 370; S. Bandžović, "Demografska deosmanizacija Balkana i odluke Berlinskog kongresa 1878. Godine," Almanah 2008, no. 41-42, p. 160; M. Hacisalınoğlu, "The Ottoman Administration of Bulgaria and Macedonia During the 19th-20th Centuries in Recent 
For example, in the Polish book about the War, Bogusław Brodecki writes that "the last atrocity against the Bulgarians during the 500 years of yoke" took place during the conflict; at the same time he briefly mentions the Muslim victims and refugees..$^{32}$ Justin McCarthy believes that it is a much wider problem: "The history of the Balkans, Caucasus, and Anatolia was written down without reference and paying attention to one of the most important players - the Muslim population." ${ }^{33}$ However, that tendency has changed deeply during the last two decades and nowadays it would be hard to claim that the topic of the Muslim victims during the Russo-Turkish War of $1877-1878$ is concealed.

The relations of the British vice-consul of Burgas, Charles Brophy, well known for his pro-Turkish and anti-Bulgarian views, ${ }^{34}$ about the acts of violence on the other population of Bulgarian lands show that Muslims were not the only victims of the War, as it is often represented by the Western and Turkish historiography nowadays. ${ }^{35}$ Jews were murdered and maltreated by Russians and Bulgarians, ${ }^{36}$ Bulgarian civilians died at the hand of Turks and Circassians. In spite of other accounts of British diplomats, Brophy saw the tragedy of the whole civilian population of the Bulgarian lands, regardless of religion: ". . . this war, instead of being a war between two nations, will degenerate into massacres of men, women, and children of both religions and Roumelia will be depopulated and made a dessert." ${ }^{37}$ Bulgarians retaliated for the suppression of the April Uprising in 1876, and Muslims for the Bulgarian chetniks' activity in the $1860 \mathrm{~s}-1870 \mathrm{~s}$ and for the War pogroms organised by Cossacks. It was a spiral of violence. The Polish historian Mirosław Dymarski wrote: "Once again, the vicious circle of violence reaped a tragic harvest. The murders on the innocent

Turkish Historiography: Contributions, Deficiencies and Perspectives," Turkish Review of Balkan Studies 2006, vol. 11, pp. 85-86.

32 B. Brodecki, Szypka i Plewna 1877, pp. 73, 81-82.

${ }_{33}$ Дж. Маккарти, Смърт и изгнание, pp. 13-14.

${ }^{34}$ Vide: Z. Klejn, "Polacy na czele powstania w Rodopach," Wojskowy Przeglad Historyczny 1996, no. 3, p. 142; That is why there are historians who do not recognize Brophy as a radical Turcophile. See: Дж. Маккарти, Смърт и изгнание, p. 85.

${ }^{35}$ FO, 195/1144/19-20, Brophy to Layard, Bourgas 4.06.1877; FO, 195/1144/37, Telegram from vice-consule Brophy to British Embassy (translation from Turkish), Slimnia 21.06.1877; FO, 195/1144/38, Telegram from vice-consule Brophy to British Embassy (translation from Turkish), Slimnia 22.06.1877; FO, 195/1144/67, Telegram from vice-consule Brophy to British Embassy (translation from Turkish), Therapia 2.09.1877.

${ }^{36}$ During the pogroms in Kazanl"k and Nova Zagora, Jews and Muslims were killed by Christians. "Mr. Layard to Earl of Derby, Therapia 22.08.1877" [in:] Ethnic Minorities in the Balkan States 1860 1971, vol. 1: 1860-1885, ed. B. Destani, Cambridge 2003, pp. 293-294; M. Dymarski, Konflikty na Bałkanach, p. 127; More about the pogroms on Jews during the conflict: B. Rusin, "Anti-Jewish excesses on Bulgarian territories of Ottoman Empire during Russo-Turkish war of 1877-1878," Studia z Dziejów Rosji i Europy Środkowo-Wschodniej 2016, vol. 51, no. 2, pp. 5-21.

${ }^{37}$ FO, 195/1144/45, Telegram from vice-consule Brophy to British Embassy (translation from Turkish), Slimnia 8.08.1877; See also: FO, 195/1144/47-60, Brophy to Layard, Bourgas 19.08.1877; FO, 195/1144/74, Brophy to Layard, Bourgas 12.09.1877. 
people would never have any excuse, and seeking the original reasons of the situation in Bulgaria is a futile task." 38

Thus, there were also Bulgarian victims and refugees of the War. In the summer of 1877, about 100,000 Bulgarians were fleeing from the Ottoman army, mostly from the regions of Stara Zagora, Nova Zagora, and Kazanl"k. ${ }^{39}$ Foreign correspondents wrote about 2,000 Christian refugees in Kavarna in July $1877,{ }^{40}$ and 3,000 in Sliven in August. ${ }^{41}$ Bulgarians were also concentrated in Balchik. ${ }^{42}$ The scale of the migrations of the Bulgarian population at that time can be illustrated with other data. According to Maria Todorova, during the "Great Eastern Crisis" (1875-1878), 1,000,000 Christians migrated within the Balkan Peninsula. ${ }^{43}$

Also, as in the case of Muslims, the total number of Christian victims of the War of 1877-1878 raises many doubts. The Turkish historian Kemal Karpat assumes that about 2,100 Bulgarian civilians died during the conflict. ${ }^{44}$ According to Roumen Daskalov, 150,000 Christians died at that time; ${ }^{45}$ according to Aleksiey Kalionski $75,000 .{ }^{46}$ These estimates are vastly different, but there is no doubt that the number of Bulgarian war victims is significantly lower than Muslim ones. Despite this, as in the case of the Turkish interpretation of the conflict, Bulgarians often present only the Christian victims of the Liberation War, which can be illustrated by the words of the Bulgarian politician Ivan Evstratiev Geshov: "Once again an escalation of Muslim fanaticism took place. Southern Bulgaria was left at the mercy of the Turks; once again it became a toy in the hands of the wildest desires." ${ }^{47}$

${ }^{38}$ M. Dymarski, Konflikty na Bałkanach, p. 128; The Romanian soldier Ștefan Georgescu, who took part in the War of 1877-1878, believed that the people from the Caucasus (Russian Cossacks and Ottomans Circassians) were responsible for all the crimes committed during the conflict. Ш. Джорджеску, “Спомени от времето на Войната за независимост 1877-1878 г.” [in:] Румънски пътеписи от XIX век за българските земи, съст. М. Младенова, Н. Жечев, София 1982, p. 152.

${ }^{39}$ К. Иречек, Княжество България, ч. I, p. 160; Р. Даскалов, Българското общество 1878 1939, т. 2, pp. 170-171; Ж. Назъ рска, “Малцинствено-религиозната политика в Източна Румелия (1879-1885)" [in:] Мюсюлманските общности на Балканите и в България, ред. А. Желязкова, София 1997, pp. 119-120.

40 “Commandor Durmont to Mr. Layard, Varna 25.07.1877" [in:] Ethnic Minorities, vol. 1, pp. 281282.

${ }^{41}$ FO 195/1144/47-60, Brophy to Layard, Bourgas 19.08.1877.

42 “Commandor Durmont to Mr. Layard, Varna 25.07.1877” [in:] Ethnic Minorities, vol. 1, pp. 281282.

${ }^{43}$ М. Тодорова, “Османското наследство на Балканите,” Либерален преглед 2013, ч. 1, pp. 1566-1567; See also: K. Popek, "The Bulgarian Migrations and the End of Ottoman Rule in Bulgaria (1878-1900)," Historijski Zbornik 2018, br. 1, god. LXXI, pp. 45-59.

${ }^{44}$ K. Karpat, Studies on Ottoman, p. 370.

45 Р. Даскалов, Българското общество 1878-1939, т. 2, p. 27.

46 A. Kalionski, Communities, Identities and Migrations, p. 41.

47 И.Е. Гешов, Спомени из години на борби и победи, ред. И. Бурилкова, Ц. Билярски, София 2008, p. 45. 


\section{CONTRADICTORY VISIONS OF THE WAR}

During the War, British diplomats made the accusation that the main goals of the Russians were the massive exile and extermination of the Muslim population in the Bulgarian lands, which would be the starting point for the transformation of the Eastern Balkans according to a new ethnic key - the domination of Orthodox Slavs. ${ }^{48}$ The interpretation is reflected in Western and Turkish historiography. According to these relations, the Russians and the Bulgarians would intentionally aim to cleanse all the Muslims from Bulgaria and to present it to the Sublime Porte and the Great Powers as a fait accompli. The Russian army would organise the special troops of Cossacks, whose main task would be to terrorise the Muslim civilians, to murder them, or to force them into exile. It was said that the long-term bombarding of cities was linked to a similar intention. The Russians would offer the Bulgarians land in exchange for killing their Muslims neighbors. The next step of the Romanov Empire's plan was the Russification of the Bulgarian lands. ${ }^{49}$

In Turkish and Western historiography, we can find a comparison between the Russo-Turkish War (1877-1878) and the Russian conquest of the Caucasus in the 1830s-1850s. According to that vision, Russians intentionally carried out activities leading to the "de-Islamisation" of the Balkans and the Caucasus with forced resettlement and expropriation. The cleansing of Muslims would strengthen the position of the Romanov Empire in both of these strategic regions. The War of 1877-1878 is presented as the continuation of that policy. ${ }^{50}$

There is no doubt that Muslim civilians were victims of many acts of violence committed by the Russian soldiers, Bulgarian voluntary troops (op"lchenie), and Christian neighbours. However, the opinions that these actions were a purposeful and organised project of the cleansing of Muslims, presented by the British public opinion and Turkish historians, are doubtful. There was an anti-Russian atmosphere in Great Britain in that time. The Turkish historian Salahi Ramadan Sonyel pointed

${ }^{48}$ FO 913/4/190, [Reade] to Layard, Varna 30.07.1878; "Mr. Layard to Earl of Derby, Therapia 1.08.1877" [in:] Ethnic Minorities, vol. 1, p. 291; “К. Цукић Ј. Ристићу из Беча, 17.02/1.03.1878” [in:] Србија 1878. Документи, прир. М. Бојводић, Д.Р. Живојиновић, А. Митровић, Р. Самарџић, Београд 1978, pp. 98-100.

49 Дж. Маккарти, Смърт и изгнание, pp. 83-84, 87-88; Ö. Turan, The Turkish Minority, pp. 125, 135, 137; D. Rodogn o, Against Massacre: Humanitarian Interventions in the Ottoman Empire, 1815-1914, Princeton 2012, p. 167; K. Karpat, Studies on Ottoman, pp. 353, 368; M. Dymarski, Konflikty na Batkanach, pp. 126, 128; И. Яльмов, История на турската общност в България, София 2002, p. 68; P. Üre, "Immediate Effects of the 1877-1878 Russo-Ottoman War on the Muslims of Bulgaria," History Studies 2012, vol. 13, pp. 158-159; T. Sahara, "Forced Ethnic Migrations and Modernity in the Balkans" [in:] Forced Ethnic Migrations in the Balkans: Consequences and Rebuilding of Societies, eds. K. Popova, M. Haj dinjak, Sofia-Tokio 2006, p. 27; T. Çetin, "The Socio-Economic Outcomes of the Last Turkish Migration (1989) from Bulgaria to Turkey," Turkish Studies 2008, vol. 3/4, p. 603; O. Köse, "The Policies of the Bulgarian State," p. 217; O. Turan, "Turkish Migrations from Bulgaria" [in:] Forced Ethnic Migrations, p. 80.

${ }^{50}$ T. Sahara, Forced Ethnic Migrations, p. 28; About the Russian policy in the Caucasus in the $19^{\text {th }}$ century: W. Richmond, The Circassian Genocide, New Brunswick-New Jersey-London 2013. 
out that the eruption of negative emotions towards Russians in England at that time was comparable only to the anti-Turkish moods during the April Uprising in Bulgaria in $1876 .{ }^{51}$ These accusations were part of the British propaganda linked to the imperial rivalry over influences in the region. Additionally, in the correspondence between the government in St. Petersburg and the Russian headquarters in the Balkans, there was no information about purposefully resettling the Muslim population. Due to the internal nature of these sources, we cannot expect propaganda in this case, in contrast to the British revelations about Russian genocidal plans, published in the press. In the Russian reports sent from Bulgaria, there were calls for the protection of civilians, regardless of their faith. ${ }^{52}$ Russian officers were fighting the acts of violence committed by the soldiers. ${ }^{53}$ The generals of German origin were the first to stop the Cossacks and the locals from harming the Muslim civilians. ${ }^{54}$ The Tsarist army organised humanitarian aid for Muslims refugees, which would be illogical in the context of planned ethnic cleansing. ${ }^{55}$ It is also worth noting that among the Muslim elites of the Bulgarian lands there was a group that believed Russians would succeed in calming down the situation in the region, which had been in a crisis since 1875.56 The organised and purposeful actions against the civilians would be reckless from the military point of view. It would lead to unnecessary chaos and be evidence for an unwise employment of the soldiers, who were needed mainly to fight against the Ottoman army. Even if the Slavophiles from the entourage of Tsar Alexander II promoted this kind of ideas, ${ }^{57}$ they would be difficult to accept among the Russian generals in the

${ }^{51}$ S.R. Sonye1, Minorities and the Destruction, p. 234; On the one hand, the government of Benjamin Disraeli was pro-Turkish, on the other hand, the opposition led by William Gladstone supported the Bulgarians. There were the social protests against Turkish atrocities in 1876 in England - the British society was sending petitions to the government in London calling for a change of the policy towards the Balkans. The most famous anti-Turkish manifest was the Bulgarian Horrors and Question of the East (London 1876) written by Gladstone, which was published in 200,000 copies. А. Пантев, Р. Генов, Уилям Гладстон и българите. Политика на праведна страст, София 2000, passim.

52 Руско-турската война 1877- 1878 г. Дневници, спомени, записки, кореспонденция, София 1998 , p. 209 et passim; “Обща инструкция но. 30 до княз Дондуков-Корсаков, 10.04.1878” [in:] Подбрани извори за българската история, т. 4, кн. 1: Българската държава и българите (1878-1946), съст. Г. Марков, А. Рабаджийска, Д. Илиева, Й. Колев, Я. Банков, В. Колев, Х. Темелски, София 2009, pp. 55-56; В.В. Кре стов ски, “Двадесет месеца в действуваща армия (1877-1878)" [in:] Руски пътеписи за българските земи XVII-XIX век, ред. М. Кожухарова, София 1986, pр. 365-366; В. Арденски, Загаснали огнища. Изселническите процеси сред българите мохамедани в периода 1878-1944 г., София 2005, pp. 15-16.

53 “Превод на донесение от Ф. Санки до А. Х. Леърд, 5.06.1877” [in:] Извори за историята на Добруджа, т. 4: 1853-1878 (Чуждестранни документи), ред. В. Тон е в, София 2003, pp. 382-383; "Писмо от началникщаба на Действаща армия до командващия Северния ордял П.С. Вановски, Сан Стефано 21.06.1878” [in:] След Сан Стефано, pp. 106-107.

${ }_{54}$ Ö. Turan, The Turkish Minority, pp. 140-142.

${ }_{55}$ FO, 913/4/292-293, Dalziel to Reade, Varna 10.02.1878; Репортажи за Освободителната война 1877-1878, съст. Л. Ген ова, София 1978, pp. 71-72.

${ }^{56}$ FO, 195/1144/47, Brophy to Layard, Bourgas 19.08.1877.

${ }^{57}$ K. Karpat, Studies on Ottoman, p. 386. 
Balkans, who were focused on the military success in the War. ${ }^{58}$ This situation could be compared to the reluctance of the Bulgarian officers to the Christianisation action in the Rhodope Mountains during the Balkan Wars (1912-1913), which was carried out by the Orthodox Church with the support of the Bulgarian government and local authorities. The army was the one of the few milieus which were counteracting the plan; not in the name of religious tolerance, however, but because of tactical motives. According to the Bulgarian generals, the action was only leading to unnecessary perturbation and social tension, which could have an unfavourable effect on the result of the war. It was quite interesting due to the fact that the officers had been one of the most anti-Islamic groups in Bulgaria at the turn of the $19^{\text {th }}$ and $20^{\text {th }}$ centuries. ${ }^{59}$

This does not mean, however, that the Russians were not responsible for the tragedy that happened in Bulgaria in 1877-1878. Even if the violence against civilians was not planned, it does not detract from the fact that we were dealing with largescale murders and displacements. Just as the Ottoman Empire was responsible for the tragedy of the April Uprising of 1876, even if the Sublime Porta did not give a clear order to massacre Bulgarians and the situation got out of hand, Russia was also fully responsible for the actions of its soldiers in the Balkans during the War.

There are other controversial opinions in historiography about the Bulgarian Liberation War. The American historian Justin McCarthy saw the War of 1877-1878 as a rarity in the context of the war standard of the $19^{\text {th }}$ century because of the scale of civilian suffering. ${ }^{60}$ Indeed, as Jürgen Osterhammel remarks:

The few wars which took place at that time [in the $19^{\text {th }}$ century - K.P.] did not last long, nor were they total. In comparison with the earlier and later wars in Europe, as well as elsewhere, the distinction between the fighting armies and the civilian population was respected more. It was one of the "great and so far underrated cultural achievements of the century."

The Bulgarian Liberation War could be recognised as "a rarity" in terms of civilian victims according to $19^{\text {th }}$-century standards, but not in the context of Balkan history ${ }^{62}$ First of all, the conviction that the War of $1877-1878$ was particularly brutal is a result of the unfounded theory that the Russians carried out purposeful actions against the Muslim civilians. Secondly, the wars and uprising in the $19^{\text {th }}$-century Balkans resulted in comparable suffering and tragedy of the civilians, who died during the sieges or bombardments of cities, in the pogroms, due to the illness and hunger. The people were forced into refuge as well. For example, in 1804-1815 two Serbian Uprisings took place in the Pashalik of Belgrade, during which there were pogroms

${ }^{58}$ K. Popek, "Muhadżirowie. Uwagi na temat emigracji muzułmanów z ziem bułgarskich na przełomie XIX i XX wieku,” Balcanica Posnaniensia. Acta et studia 2016, vol. 23, pp. 49-50.

59 С. Елдъров, “Българската православна църква и българите мюсюлмани 1878-1944 г.” [in:] История на мюсюлманската култура по българските земи, т. 7, ред. Р. Градева, София 1997, pp. 623-625.

${ }^{60}$ Vide: Дж. Маккарти, Смърт и изгнание, pp. 83-84.

${ }^{61}$ J. Osterhammel, Historia XIX wieku. Przeobrażenie świata, trans. I. DrozdowskaBroering, J. Kałążny, A. Peszke, K. Śliwińska, Poznań 2013, p. 654.

${ }^{62}$ Ibidem, pp. 191-194. 
of the Muslims and a mass exodus of that population. $.^{63} 50,000$ Muslims had left the territory by 1813. During the Greek War of Independence, 25,000 Muslims were killed and thousands emigrated to the North or to Anatolia. ${ }^{64}$

Bulgarian historiography often justifies actions of the Russian army and the Bulgarians during the Liberation War. It is claimed that the Tsarist soldiers treated the Muslim and Christian civilians equally. The Turkish emigration resulted only from the Sublime Porte's propaganda, which spread false gossip about pogroms. According to this vision, the phenomenon was not a massive one, only affecting the people guilty of the atrocities of 1876, Ottoman officials, and Muslim religious leaders, who took refuge. They were closely associated with the Turkish government system and responsible for the discrimination and repressions against the rayah. According to Bulgarian historians, Muslims from the Rhodope Mountains welcomed the Russian Army as their liberators. Any accusation about pogroms, acts of vandalism, or repressions against the civilians were treated as a false vision created by the Turkish and Western propaganda. As they believed, the Circassians and deserters from the Ottoman army were guilty of all the crimes committed in the Bulgarian lands in 1877 1878. ${ }^{65}$ Some of the commentators pointed out that the Muslims used the scorched earth policy during the evacuation. ${ }^{66}$ During the War, the Bulgarians denied their responsibility for these crimes. On $8^{\text {th }}$ of June 1878, the Bulgarian delegation of Stoyan Chomakov, Stefan Panaretov, and Dimit"r Grekov came to the British consulate in Constantinople. They claimed that only the Russians were guilty of the exodus and pogroms against the Muslims in the Balkans. ${ }^{67}$ Meanwhile, the Russian diplomats denied the tragedy of the Muslim community during the War and claimed that there had been no pogroms or resettlement at all. ${ }^{68}$

${ }^{63}$ T. Sahara, Forced Ethnic Migrations, pp. 26-27; See more S. Bandžović, Bošnjaci i deosmanizacija Balkana: muhadžirski pokreti i pribježišta "sultanovih musafira" (1683.-1875.), Sarajevo 2013, pp. 215-261.

${ }^{64}$ W. Höpken, "Der Exodus," pp. 312-313; H. Poulton, "Changing Notions of National Identity among Muslims in Thrace and Macedonia: Turks, Pomaks and Roma" [in:] Muslim Identity and the Balkan States, eds. H. Poulton, S. Taji-Farouki, London 1997, pp. 82-83; about the violence in the Balkans: B. Jezernik, Dzika Europa. Bałkany w oczach zachodnich podróżników, trans. P. Oczko, Kraków 2013, pp. 123-150; about the Muslim exodus during the Greek War of Independence see: K. Popek, "The Emigration of Muslims from the Greek state in the 19th century. An Outline," Balcanica Posnaniensia. Acta et studia 2020, vol. 27, pp. 99-107.

${ }_{65}$ Д. Илков, Принос към история на град Стара Загора, Пловдив 1908, p. 232; Репортажи за Освободителната война, р. 212; Из миналото на българите мохамедани в Родопите, ред. Х. Христов, В. Хаджиниколов, София 1958, pp. 103-104; S. Raichevsky, The Mohammedan Bulgarians (Pomaks), trans. M. Pencheva, Sofia 2004, pp. 77-78; А. В з л е в, Тъмръи, София 1973, pp. 185-186; В. Арденск и, Загаснали огнища, pp. 12-14; В.Н. Виноградов, "Последняя русскотурецкая война," p. 207; R. Daskalov, The Making of Nation in the Balkans. Historiography of the Bulgarian Revival, Budapest-New York 2004, pp. 197-218.

${ }^{66}$ Ш. Джордже ску, “Спомени от времето на Войната за независимост,” р. 152.

${ }_{67}$ “Mr. Layard to Marquis of Salisbury, Therapia 8.06.1878” [in:] Ethnic Minorities, vol. 1, p. 301.

${ }^{68}$ Дж. Маккарти, Смърт и изгнание, pp. 116-117. 


\section{CONCLUSION}

The difficulty of characterising the War stems from many contradictory relations about these events. It is not only related to the motivations of the Bulgarian and Turkish historians, who want to present their national visions of history, but to the source materials as well. In historiography and the sources, Bulgarians have presented Muslims as oppressors and Christians as victims, and Turks vice versa: Muslims are sufferers and Bulgarians are tormentors. The representative example is the fate of the Stara Zagora (Eski Zağra) during the War - the city was burned down in July 1877. The Bulgarians accused the Turkish troops led by Suleyman Pasha of that crime. After setting fire to Christian houses, the Ottoman soldiers blocked the escape route some of the Bulgarians were murdered, some of them were held captive ${ }^{69}$ According to Bulgarian accounts, the Muslim inhabitants of the city took part in the atrocities. No Bulgarian man survived, the women and children were enslaved. Nobody tried to extinguish the burning Stara Zagora, in which many Bulgarians died. Only the Muslim mahala and the outermost districts survived. After the troops of Suleyman Pasha left the city, the local Muslims ran away to Plovdiv, Adrianople, and Constantinople, afraid of Russian retaliation. According to this version, the Tsarist Army entered a deserted and ruined city. ${ }^{70}$ Turkish historians hold a different vision of the burning down of Stara Zagora. They claim that Russians were guilty of the arson and massacre of the city. According to the Turkish sources, the Tsarist Army murdered 1,100 Muslims over eleven days. It would have been a much higher number if 25,000 Muslims had not escaped from the city in advance. ${ }^{71}$ These contradictory visions of the destruction of Stara Zagora are one of the many examples of extreme assessments of the events of the War of 1877-1878 from the Bulgarian and Turkish perspective.

The problem with the above historiographical visions of the War is also related to the reliability of the Western diplomatic sources and materials prepared by correspondents. These accounts of cruelties committed by Muslims, Bulgarians, or Rus-

${ }^{69}$ Also, there were other relations about the kidnapping of the Bulgarian woman and children during the Bulgarian Liberation War, however, the phenomenon had not massive scale. [Vide: Асимилаторската политика на турските завоеватели. Сборник от документи за помохамеданчвания и потурчвания $X V-X I X$ в., съст. П. Петров, София 1962, pp. 364-366]. For example, Stanka Nikolova from the villiage of Vakarel was kidnapped by Izet Bey in 1877. In 1879, they lived in Nevrokop, in the Ottoman Empire (nowadays: Gotse Delchev). Stanka's mother, Petka, was trying to bring her daughter back to Bulgaria. Seе: ЦДА, ф. 321к оп. 1 а.е. 8 л. 108, Прошение от Петка Николова от с. Вакарел до Самоковски окръжен началник, Вакарел 30.11.1879 [date of receipt]; ЦДА, ф. 321к оп. 1 а.е. 8 л. 109, От Министерство на външните работи и изповеданията до Дипломатическо агентство в Цариград, София 8.12.1879.

70 Д. Ил ко в, Принос към история на град Стара Загора, pp. 229-235; К. Иреч ек, Княжество България. Негова повърхнина, природа, население, духовна култура, управление и новейша история, ч. II: Пътувания по България, Пловдив 1899, pp. 169-172; M. Dymarski, Konflikty na Batkanach, pp. 127; B. Brodecki, Szypka i Plewna 1877, pp. 74-78.

${ }^{71}$ Ö. Turan, The Turkish Minority, pp. 128-129; И. Яльмов, История на турската общност, p. 68 . 
sians were often exaggerated. The number of victims was overestimated, the visions of massacres demonised, the descriptions of the suffering of civilians colourised. On the one hand, it was a result of journalistic sensationalism; ${ }^{72}$ on the other hand, it stemmed from stereotypes about the Balkans, commonly associated with barbarism, pogroms, and brutality, which were so precisely described by Maria Todorova. ${ }^{73}$

Literature and culture played an important role in the consolidation of these contradictory visions about the War of 1877-1878 in the Bulgarian and Turkish historical narratives. It is also worth to mention the most popular literary images: Turkish works by Aşık Hıfzı or Hüseyin Recep Efendi ${ }^{74}$ in the case of Bulgarians - the writing of Ivan Vazov, for example the last poem of the Epic of the Forgotten (Enопея на забравените), The Resistance of Shipka (Опьлченците на Шипка). ${ }^{75}$

The pessimistic predictions of Charles Brophy that the only prospect for peace in the Bulgarian lands is a population exchange and a separation of the Muslims and the Christians fortunately did not turn out to be true. ${ }^{76}$ Despite the mutual atrocities of the "Great Eastern Crisis," after 1878, the society of Bulgarian lands gradually rebuilt its relations. After the chaos prevalent immediately after the War, the new Bulgarian state pursued a rather liberal minority policy toward Muslims in 1878-1912. The decades of the 1870s and 1880s saw numerous anti-Muslim actions, which were caused by contemporary problems linked to the regulation of land property, rebellions, brigand activity, and mass emigration. After the Union of 1885 , Sofia started to allow Muslims to live as they wanted, by granting them wide autonomy in education, administration, and religion. There were no assimilative actions or deportations at that time; quite the contrary, the Bulgarian state protected Muslims from the Orthodox Church and supported their schools and mosques financially. For $19^{\text {th }}$-century standards, this kind of approach to a religious minority can be called tolerant. ${ }^{77}$ Nonetheless, during the $20^{\text {th }}$ century, the Bulgarian-Turkish relations were no longer so harmonious, as shown by compulsory assimilative actions during the First Balkan War (1912) and the Communist era in the 1970s and the 1980s. ${ }^{78}$

72 "Mr. Layard to Earl of Derby, Therapia 1.08.1877” [in:] Ethnic Minorities, vol. 1, p. 292.

${ }^{73}$ M. Todorova, Bałkany wyobrażone, trans. P. Szymor, M. Budzińska, Wołowiec 2008, pp. 221-223 et passim.

74 И. Ялъмов, Етнокултурна и религиозна идентичност на турската общност в България, София 2014, pp. 190, 212; idem, “Ислямското културно наследство по българските земи," Годишник на Вишия ислямски институт 2010, бр. 2, pp. 33-34.

${ }^{75}$ И. Вазов, Опълченците на Шипка, 11.08.1877, www.slovo.bg/showwork. php3?AuID=14\&WorkID=920\&Level=2 [access: December 13, 2017].

${ }^{76}$ FO, 195/1144/47, Brophy to Layard, Bourgas 19.08.1877.

${ }^{77}$ K. Popek, "Cruel Tormentor or Good Neighbour? Stereotype of the Turk and Bulgarian State Policy Towards the Muslim Minority in 1878-1912," Slavonic Review 2017, no. 2, pp. 282-283.

${ }^{78}$ Idem, "Mniejszość muzułmańska w Bułgarii," Przeglad Geopolityczny 2015, vol. 14, pp. 71-85. 


\section{BIBLIOGRAPHY}

\section{Archival Materials}

Central State Archive in Sofia (ЦДА)

ф. 321к (Дипломатическо агентство в Цариград)

Foreign Office Archives, Public Record Office, London (FO)

195 (Embassy and Consulates, Turkey, formerly Ottoman Empire: General Correspondence, Bulgaria)

881 (Foreign Office: Confidential Print)

913 (Consulates, Varna and Rustchuk, Bulgaria, formerly Ottoman Empire: General Correspondence)

\section{Printed Sources}

Ethnic Minorities in the Balkan States 1860-1971, vol. 1: 1860-1885, ed. B. Destani, Cambridge 2003.

Gladstone W., Horrors and Question of the East, London 1876.

Rumeli'den Türk Göçleri. Belgeler, cilt I: Doksanüç Muhacereti. 1877-1878, ed. B.N. Şi imşir, Ankara 1968.

Асимилаторската политика на турските завоеватели. Сборник от документи за помохамеданчвания и потурчвания $X V-X I X$ в., ред. П. Петров, София 1962.

Гешов И.Е., Спомени из години на борби и победи, ред. И. Бурилкова, Ц. Билярски, София 2008.

Извори за историята на Добруджа, т. 4: 1853-1878 (Чуждестранни документи), ред. съст. В. Тонев, София 2003.

Илков Д., Принос към история на град Стара Загора, Пловдив 1908.

Иречек К., Княжество България. Негова повърхнина, природа, население, духовна култура, управление и новейша история, ч. І: Българска държава, Пловдив 1899.

Иречек К., Княжество България. Негова повърхнина, природа, население, духовна култура, управление и новейша история, ч. ІІ: Пътувания по България, Пловдив 1899.

Иширков А., “Град Варна,” Периодическо списание 1905, кн. 65, pp. 191-237.

Подбрани извори за българската история, т. 4, кн. 1: Българската държава u българите (1878-1946), съст. Г. Марков, А. Рабаджийска, Д. Илиева, Й. Колев, Я. Банков, В. Колев, Х. Темелски, София 2009.

Репортажи за Освободителната война 1877-1878, съст. Л. Генова, София 1978.

Румънски пътеписи от ХІХ век за българските земи, съст. М. Младенова, Н. Жечев, София 1982.

Руски пътеписи за българските земи XVII-XIX век, съст. М. Кожухарова, София 1986.

Руско-турската война 1877-1878 г. Дневници, спомени, записки, кореспонденция, София 1998.

След Сан Стефано и Берлин 1878 г. Изследване, документи и материали за освобождението на Североизточна България от османска власт, съст. В. Тонев, София 1999.

Србија 1878. Документи, прир. М. Бојводић, Д.Р. Живојиновић, А. Митровић, Р. Самарџић, Београд 1978. 


\section{Literature}

Bandžović S., Bošnjaci i deosmanizacija Balkana: muhadžirski pokreti i pribježišta „,sultanovih musafira" (1683.-1875.), Sarajevo 2013.

Bandžović S., "Demografska deosmanizacija Balkana i odluke Berlinskog kongresa 1878. godine," Almanah 2008, no. 41-42, pp. 143-185.

Brodecki B., Szypka i Plewna 1877, Warszawa 1986.

Courbage Y., "Demographic Transition among Muslims in Eastern Europe," Population: An English Selection 1992, vol. 4, pp. 161-186.

Crampton R., Bulgaria, Oxford 2007.

Çetin T., "The Socio-Economic Outcomes of the Last Turkish Migration (1989) from Bulgaria to Turkey," Turkish Studies 2008, vol. 3/4, pp. 602-632.

Daskalov R., The Making of Nation in the Balkans. Historiography of the Bulgarian Revival, Budapest-New York 2004.

Detrez R., Historical Dictionary of Bulgaria, Lanham-Toronto-Oxford 2006.

Dymarski M., Konflikty na Bałkanach $w$ okresie ksztaltowania się państw narodowych w XIX i na poczatku XX wieku, Wrocław 2010.

Eminov A., "Islam and Muslims in Bulgaria: A Brief History," Islamic Studies 1997, vol. 36 , no. 2-3, pp. 209-241.

Eminov A., "The Status of Islam and Muslims in Bulgaria," Journal Institute of Muslim Minority Affairs 1987, vol. 8:2, pp. 278-301.

Eminov A., Turkish and Other Muslim Minorities in Bulgaria, London 1997.

Giza A., Stowianofile rosyjscy wobec kryzysu bałkańskiego w latach: 1875-1878, Wrocław 1982.

Gruber S.D., Selected Muslim Historic Monuments and Sites in Bulgaria, Washington 2010.

Hacisalınoğlu M., "The Ottoman Administration of Bulgaria and Macedonia During the 19th-20th Centuries in Recent Turkish Historiography: Contributions, Deficiencies and Perspectives," Turkish Review of Balkan Studies 2006, vol. 11, pp. 85-123.

Holt W., The Balkan Reconquista and Turkey's Forgotten Refugee Crisis, Salt Lake City 2019.

Höpken W., "Der Exodus: Muslimische Emigration aus Bulgarien im 19. und 20. Jahrundert" [in:] Osmanen und Islam in Südosteuropa, eds. R. Lauer, H.G. Majer, BerlinBoston 2014, pp. 303-433.

Jezernik B., Dzika Europa. Bałkany w oczach zachodnich podróżników, trans. P. Oczko, Kraków 2013.

Kalionski A., Communities, Identities and Migrations in Southeast Europe, Sofia 2014.

Karpat K., "Introduction: Bulgarian Way of Nation Building and the Turkish Minority" [in:] The Turks of Bulgaria: The History, Culture and Political Fate of a Minority, ed. K. Karpat, Istanbul 1990, pp. 1-22.

Karpat K., Ottoman Population 1830-1914. Demographic and Social Characteristic, London 1985.

Karpat K., Studies on Ottoman Social and Political History, Leiden-Boston-Koln 2002.

Klejn Z., "Polacy na czele powstania w Rodopach," Wojskowy Przeglad Historyczny 1996, no. 3, pp. 128-156.

Köse O., "The Policies of the Bulgarian State towards the Minorities (1878-1914)," Sosyal Bilimler Araştırmaları Dergisi 2012, vol. 3(6), pp. 216-239.

Leksykon tradycji butgarskiej, ed. G. Szwat-Gyłybowa, Warszawa 2011.

Mazower M., The Balkans: From the End of Byzantium to the Present Day, Phoenix 2002.

McCarthy J., "Muslim in Ottoman Europe: Population from 1880 to 1912," Nationalities Papers 2000, vol. 28, no. 1, pp. 29-43. 
Memişoglu H., The Education of the Turks in Bulgaria, Ankara 1992.

Methodieva M., Pan-Islam, the Porte and Education: Ottoman Support for Muslim Schools in the Bulgarian Principality, 1878-1908, Ankara 2001. (unpublished thesis)

Mirkova A.M., "'Population Politics' at the End of Empire: Migration and Sovereignty in Ottoman Eastern Rumelia, 1877-1886," Comparative Studies in Society and History 2013, 55(4), pp. 955-985.

Osterhammel J., Historia XIX wieku. Przeobrażenie świata, trans. I. DrozdowskaBroering, J. Kałążny, A. Peszke, K. Śliwińska, Poznań 2013.

Özgür-Baklacioglu N., "Dual Citizenship, Extraterritorial Elections and National Policies: Turkish Dual Citizens in the Bulgarian-Turkish Political Sphere," Slavic Eurasian Studies 2006, no. 9: Beyond Sovereignty: From Status Law to Transnational Citizenship?, pp. 319-358.

Pandevska M., "Migration of the Muhajirs in Macedonia during the Great Eastern Crisis (1875-1881)," Balcanica Posnaniensia. Acta et studia 2001, vol. 21 22, pp. 103-111.

Pekesen B., "Expulsion and Emigration of the Muslims from the Balkans," European History Online, March 7, 2012, http://www.ieg-ego.eu/pekesenb-2011-en [accessed: October $18,2015]$.

Popek K., "Cruel Tormentor or Good Neighbour? Stereotype of the Turk and Bulgarian State Policy Towards the Muslim Minority in 1878-1912," Slavonic Review 2017, no. 2, pp. 261-284.

Popek K., "Mniejszość muzułmańska w Bułgarii," Przegląd Geopolityczny 2015, vol. 14, pp. 71-85.

Popek K., "Muhadżirowie. Uwagi na temat emigracji muzułmanów z ziem bułgarskich na przełomie XIX i XX wieku," Balcanica Posnaniensia. Acta et studia 2016, vol. 23, pp. 47-69.

Popek K., "The Bulgarian Migrations and the End of Ottoman Rule in Bulgaria (18781900)," Historijski Zbornik 2018, br. 1, god. LXXI, pp. 45-59.

Popek K., "The Emigration of Muslims from the Greek state in the 19th century. An Outline," Balcanica Posnaniensia. Acta et studia 2020, vol. 27, pp. 97-122.

Poulton H., "Changing Notions of National Identity among Muslims in Thrace and Macedonia: Turks, Pomaks and Roma" [in:] Muslim Identity and the Balkan States, eds. H. Poulton, S. Taji-Farouki, London 1997, pp. 82-102.

Raichevsky S., The Mohammedan Bulgarians (Pomaks), trans. M. Pencheva, Sofia 2004.

Rodogno D., Against Massacre: Humanitarian Interventions in the Ottoman Empire, 18151914, Princeton 2012.

Richmond W., The Circassian Genocide, New Brunswick-New Jersey-London 2013.

Rusin B., "Anti-Jewish excesses on Bulgarian territories of Ottoman Empire during RussoTurkish war of 1877-1878," Studia z Dziejów Rosji i Europy Środkowo-Wschodniej 2016, vol. 51, no. 2, pp. 5-20.

Sahara T., "Forced Ethnic Migrations and Modernity in the Balkans" [in:] Forced Ethnic Migrations in the Balkans: Consequences and Rebuilding of Societies, eds. K. Popova, M. Hajdinjak, Sofia-Tokio 2006, pp. 23-41.

Sonyel R., Minorities and the Destruction of the Ottoman Empire, Ankara 1993.

Şen B., "Empires from the Margin: Bosnian Muslim Migrants between Ottoman Empire and the Austro-Hungarian Empire - Petitions of the Returnees," Balkanistic Forum 2015, no. 3: Emigrants and Minorities: The Silenced Memory of the Russo-Ottoman War 18771878, pp. 13-29.

Şimşir B., The Turks of Bulgaria (1878-1985), London 1988.

The Human Rights of Muslims in Bulgaria in Law and Politics since 1878, Sofia 2003.

Todorova M., Batkany wyobrażone, trans. P. Szymor, M. Budzińska, Wołowiec 2008. 
Toumarkine A., Les migrations des populations musulmanes balkaniques en Anatolie (1876-1913), Istanbul 1995.

Turan Ö., Evered K.T., "Jadidism in South-Eastern Europe: The Influence of Ismail Bey Gaspirali among Bulgarian Turks," Middle Eastern Studies 2005, vol. 41, no. 4, pp. 481-502.

Turan Ö., The Turkish Minority in Bulgaria (1878-1908), Ankara 1998.

Turan O., "Turkish Migrations from Bulgaria" [in:] Forced Ethnic Migrations in the Balkans: Consequences and Rebuilding of Societies, eds. K. Popova, M. Hajdinjak, Sofia-Tokio 2006, pp. 77-93.

Üre P., "Immediate Effects of the 1877-1878 Russo-Ottoman War on the Muslims of Bulgaria," History Studies 2012, vol. 13, pp. 153-170.

Арденски В., Загаснали огнища. Изселническите прочеси сред българите мохамедани в периода 1878-1944 г., София 2005.

Билунов Б. Н., Болгария и Россия, Москва 1996.

Вазов И., Опьлченциче на Шипка, 11.08.1877, www.slovo.bg/showwork. php3?AuID=14\&WorkID=920\&Level=2 [accessed: December 13, 2017].

Виноградов В.Н., “Боевое содружество народов России и Балкан во время русскотурецкой войны 1877-1878 гг.” [in:] Центральная и Юго-Восточная Европа в Новое время, Москва 1974, pp. 205-213.

Виноградов В.Н., “Последняя русско-туреикая война 1877-1878годов” [in:] История Балкан: Судьбоносное двадиатилетие (1856-1878 г2.), ред. В.Н. Виноградов, Москва 2012, pp. 299-327.

Вълчев А., Тъмръи, София 1973.

Генов Ц., Освободителната война 1877-1878, София 1978.

Георгиев Г., Освободителната война 1877-1878: еничиклопедичен справочник, София 1986.

Даскалов Р., Българското общество 1878-1939, т. 2: Население, общество, култура, София 2005.

Дойнов С., Българската общественост и Руско-турската освободителна война (1877-1878), София 1978.

Елдъров С., “Българската православна църква и българите мюсюлмани 1878-1944 г.” [in:] История на мюсюлманската култура по българските земи, т. 7, ред. Р. Градева, София 1997, pp. 592-639.

Из миналото на българите мохамедани в Родопите, ред. Х. Христов, В. Хаджиниколов, София 1958.

Илиева Н., Турската етническа група в България (1878-2001), София 2010.

Кос ев К., Дойнов С., От Шипка и Плевен до Сан Стефано и Берлин, София 2007.

Лори Б., Съдбата на османското наследство. Българската градска култура 1878 1900, прев. Л. Янакиева, София 2002.

Маева М.М., Българските туричи-преселеници в Република Турциия (Култура и идентичност), София 2006.

Маккарти Дж., Смърт и изгнание: Етническото прочистване на османските мюсюлмани (1821-1922), прев. К. Панайотова, София 2010.

Назърска Ж., “Малцинствено-религиозната политика в Източна Румелия (18791885)" [in:] Мюсюлманските общности на Балканите и в България, ред. А. Желяз ков а, София 1997, pp. 113-235.

Пандевска М., Присилни миграции во Македонија во годините на Големата источна криза (1875-1881), Скопје 1993.

Пантев А., Генов Р., Уилям Гладстон и българите. Политика на праведна страст, 
София 2000.

Россия и Болгария: К 125-летию русско-турецкой войны 1875-1878 г2., Москва 2006.

Саздов Д., Лалков М., Митев Т., Мишев Р., Мигев В., История на Третата българска държава, София 1992.

Стоянов В., Турското население в България между полюсите на етническата политика, София 1997.

Страници от българската история. Очерк за ислямизираните българи и националновъзродителния процес, ред. Х. Христов, София 1989.

Тафрова М., Танзиматът, вилаетската реформа и българите. Администрацията на Дунавския вилает (1864-1876), София 2010.

Тодоров Н., Балканският град XV-XIX век. Сочиално-икономическо и демографско развитие, София 1972.

Тодорова М., “Османското наследство на Балканите,” Либерален преглед 2013, ч. 1, pp. 1541-1579.

Ялъмов И., Етнокултурна и религиозна идентичност на турската общност в България, София 2014.

Ялъмов И., “Ислямското културно наследство по българските земи," Годишник на Вишия ислямски институт 2010, бр. 2, pp. 5-58.

Яльмов И., История на турската общност в България, София 2002. 